\title{
Perilous Wages: Predicaments of Female Labour Migration from Bangladesh to the Middle East
}

\author{
M. Saiful Islam \\ Associate Professor \\ Department of Development Studies \\ University of Dhaka \\ Dhaka - 1000, Bangladesh \\ E-mail: saiful.islam@du.ac.bd
}

Received: December 24, 2017

Accepted: February 20, 2018 Published: March 15, 2018

doi:10.5296/iss.v6i1.14933

URL: http://dx.doi.org/10.5296/iss.v6i1.14933

\begin{abstract}
The recent bilateral agreement between Bangladesh and the Gulf Cooperation Countries (GCC) has facilitated migration of female domestic workers, which has opened up an opportunity as well as challenge for Bangladesh. Opportunities are quite significant in a sense that male migration has already been saturated in the GCC countries which has a major impact on the flow of remittances. The abundant and employable female labour force in Bangladesh could easily contribute to this international labour migration, and thereby add to the national economic development. There are serious problems as well since many Bangladeshi female domestic workers are reported to be exploited, sexually abused and raped by the middle man, recruiting agents, and the overseas employers. Many women fled from their employer and sought shelter at the Bangladesh consulate in Jeddah and Riyadh, alleging that they are either being tortured, not properly fed, paid, or not given job as promised. Many female migrants left their family members and young children at home in Bangladesh, which created further social problems as women are still considered as homemakers and childcare providers in the Bangladeshi cultural context. At this backdrop, the time is up to find out ways to make female domestic migration safe and secure. Both the sending and receiving countries must come up with policies and awareness programs that would ensure safety for the female domestic workers. It requires a strong commitment from both the sending and receiving countries that the policies, acts and laws are in favour of female migrant workers. National and international NGOs, civil society and media could play vital role to adopt and implement appropriate policies for safe and sound migration of the female domestic workers.
\end{abstract}

Keywords: Female migration, Plights of female housemaid, Bangladesh, the Middle East 


\section{Macrothink}

Issues in Social Science

ISSN 2329-521X

2018, Vol. 6, No. 1

\section{Introduction}

Bangladesh is one of the largest countries in the world that sends skilled and semi-skilled workers abroad. The lion's share of the revenue of the country is generated from the remittances of the migrant workers (BMET, 2017). Although the exact number is unavailable, it is estimated that nearly 50 million people has migrated to other countries. Historically, migration has been an integral part of the Bangladeshis. Looking back into the pre-colonial times, people from the other parts settled in Bengal which was highly fertile but waterlogged most of the times. During the colonial period people from the West invaded the then Bengal. The British ruled over Bengal for nearly 200 years. Describing such movements of the people Gardner argues that "These constant, cross-cutting migrations are both a result of the region's turbulent history, and its turbulent environment, in which floods and cyclones mean that 'belonging' can never be guaranteed” (Gardner, 2009: p. 233).

Today, people of Bangladesh are fast moving both internally and globally, predominantly to the Middle Eastern, Southeast Asia and other parts of the world (Shah, 2017). It has been estimated that since 1976 to 2002, more than three million Bangladeshis have migrated overseas, who went mostly on short term work contracts (Gardner, 2009). Except for some middle class professionals, most of the migrants are usually unskilled/semi-skilled wage workers, who mostly contribute to the dangerous and low paid sectors of the international labour market. They mostly take up the jobs that are unlikely to be done by the local natives. Illegal migration is another unfortunate aspect of Bangladeshi labour migration. There has been a number of studies that show how these migrants take huge risks in their attempts to migrate; many of them die in the sea while crossing, caught, or even deported before reaching to their destinations and earning wages. In their home country, many are cheated by the middle man or dalal (Gardner, 2009; Frantz, 2017; Alhasan, 2017; Kibria, 2011; Papademetriou, 2005).

Although migration from Bangladesh to overseas has historically been dominated by the male migrants, until recently Government of Bangladesh has come up with an understanding with Saudi Arabia and other Middle Eastern countries to send female domestic workers. Sending female domestic workers to the Gulf countries is a relatively new experience for Bangladesh. Female labour market in the Gulf was predominantly occupied by the female migrants from Indonesia and Philippines (Mahdavi, 2017; Alsharif, 2017; Shah, 2008; Rachel, 2004). However, these two countries recently decided not to send female domestic helpers in Saudi Arabia, which has opened up a new opportunity for Bangladesh to fill-up the vacuum. In 2015, 20,915 female domestic workers were sent to Saudi Arabia and it is expected that 500,000 more to be sent gradually (BMET, 2017). Both Bangladesh and the Gulf countries, predominantly Saudi Arabia, see migrant domestic workers as a way of promoting national economic development (Pakkiasamy, 2004). Bangladesh focuses on creating employment and generating foreign exchange through remittances, and Saudi Arabia's economy benefits from the provisions of housemaids at low cost that make their women free to take part into education, job, and other activities.

In this article I highlight on three objectives relevant to Bangladeshi female labour migration 
to the Gulf countries. The first objective is to understand the dynamics of recent female migration and employment patterns of Bangladeshi domestic workers in the Middle Eastern countries with a focus on how the state manages such female overseas migration. The second objective is to examine how the state in the Gulf countries play a role to pull migrant workers, protect their rights, and respond to abuses of the migrant female domestic workers.

The third objective focuses on the role of NGOs and civil society organizations to pressurize both the sending and receiving countries to ensure protections for migrant workers. This study further highlights some of the policy recommendations for the sending and receiving countries to protect rights of the female domestic workers and ensure their safe workplace.

\section{Sending Female Labour Migrants: How Bangladesh Manages the Process}

At the very outset it can be said that the Government of Bangladesh (GoB) has become particularly successful in creating job market for the females particularly in Saudi Arabia and other Middle Eastern countries. The GoB has managed to negotiate with Saudi Arabia so that job markets for the domestic helpers could be created for the interested female labourers of Bangladesh. Upon various government level initiatives and negotiations, Saudi Arabia has finally agreed to lift a seven-year ban on hiring Bangladeshi workers in January 2015 with a bilateral diplomatic agreement to receive 500,000 female housemaids (Saudi Gazette, 2015).

Migration from Bangladesh is regulated by at least three legal and regulatory frameworks: internal laws of both sending and receiving countries; bilateral agreements between two countries, and agreements between government and private recruitment agencies to facilitate migration process in case government does not directly recruit migrants. The GoB has also enacted different laws in order to ensure labour market creation so that maximum number of people from Bangladesh can work abroad. Other laws are also in place to make sure the protection and welfare of the migrant who are working abroad. Although the state routinely claims that enough initiatives have been taken to ensure security and overall well-being of the migrants, there has been a number of reports and studies that show migration process in Bangladesh is still a matter of complicated, corrupt and unsafe procedure (Fargues and De Bel-air, 2015; Asia Foundation, 2013; Karim, 2017). Bangladeshi migration context is heavily contaminated by illegal, undocumented, unauthorized, clandestine and dalali procedures.

In order to expedite, control and regulate the process of international migration, the GoB has established the Bureau of Manpower, Employment, and Training (BMET). The main objective of establishing this bureau is to provide training and entrepreneurial support to the aspirant migrants who are willing to work abroad. Through this bureau GoB collects most of the information about the migrants. Another objective of this bureau is to ensure that migrants know about the rules and regulations abroad and how to comply with them. It also trains migrants on how to send remittances and best use it in the home country. This bureau also helps relatives of the migrants to bring dead bodies of the migrants who either die abroad or stranded for whatever reasons. Overall, BMET is responsible for overall management and well-being of the Bangladeshi labour migrants abroad. This bureau is, however, affected by a number of inadequacies such as insufficient budgetary allocations, pervasive corruption, and 


\section{1) Macrothink}

Issues in Social Science

ISSN 2329-521X

2018, Vol. 6, No. 1

overall mismanagement of the office. Such problems vehemently impede services of this important organization.

The different laws, acts and policies that the GoB has enacted reflect the government's intention to ensure overall well-being and protection of the migrants who are working abroad. Some of the major acts and policies of the Government of Bangladesh are as follows:

- Emigration Ordinance 1982

- Recruitment Agency and License Policy (2002)

- Wage Earners Welfare Fund Rules (2002)

- Foreign Employment Policy (2006)

- Selection of Commercially Important Persons (CIP) (2006)

- Expatriates' Welfare Act (2010)

- Special facilities for remittance sender nonresident Bangladeshis (2008)

With the bilateral agreement in the beginning of 2015 between receiving countries in the Gulf and Bangladesh to hire housemaids, the Government of Bangladesh permitted private agencies from Bangladesh to recruit Bangladeshi female nationals to work in the Middle Eastern countries. The Government of Bangladesh was particularly enthusiastic about the prospects of female labour migration which was highly valued as a potential source of overseas employment opportunity for many unemployed or underemployed Bangladeshi female nationals. It is believed that these female labour could be a source of population divided who could bring crucial foreign remittances for the overall development of the country. Against the demand of 500,000 housemaids, in the first year of recruitment, nearly 21,000 fully documented workers left Bangladesh for Saudi Arabia, and these numbers soon climbed rapidly as 121,925 women workers joined overseas employment which was about $12 \%$ of the total migrant workforce from Bangladesh (Dhaka Tribune, 2017). The Government of Bangladesh aggressively promoted the process of female overseas domestic help job opportunities so that more women could join the workforce. It made efforts to set up training programs which were primarily targeted to familiarize aspirant female domestic helpers to know more about domestic service skills, teaching language and customs of the Gulf countries.

Although it is too early to assess the prospects of sending housemaids right now, several newspaper reports have already documented the abusive working condition of the housemaids. I will come back to this point after I highlight some of the state policies in the receiving countries regarding hiring housemaid policies and practices.

\section{Receiving Female Migrants: The Role of the Gulf States}

Since the early 1980s, the government of Saudi Arabia strictly controlled its immigration policies with specific focus on creating job opportunities for the local people, which many scholars popularly call as "Saudisation" (Azhari, 2017; Almutairi, 2017). One of the main 


\section{Macrothink}

Issues in Social Science

ISSN 2329-521X

2018, Vol. 6, No. 1

objectives of controlling the Saudi labour market was to replace foreign workers with Saudi nationals (De Bel-Air, 2018). Such policies, however, did not become effective for several reasons. First, the citizens of Saudi Arabia and other Gulf countries did not consider foreign migrant workers to be a real threat to their occupations due to the understanding that there existed a dual labour market for the local people. For example, local citizens tend to prefer employment in the public sector, whereas migrants take on blue-collar jobs that the locals are unlikely to be interested. Second, rather than considering foreign workers as threat, most local people considered migrants as the blessings which benefitted them in many ways. For example, they could rely on these migrants to bring down the prices of services, on the other hand, employers find them as a source of cheap and temporary labour (Silvey, 2004; De Bel-Air, 2018).

There has also been a demand for the domestic helpers which was geared up due to the Saudi government's decision to include Saudi women in higher education, a call for Saudi women to join labor force, and the perceived socio-cultural restrictions of Saudi women's mobility which restricted the day-to-day necessities of the Saudi families. Therefore, the liberal education and work policy for the Saudi government increasingly attracted women for work and education that subsequently increased their absence in the family and home. Such changes in the policies and job market opening for women in the 1970s created a space for growing demand of foreign domestic helpers. Many Saudi families were obliged to hire foreign female domestic helpers to maintain the household chores.

Such an economic boost-up did not last long as the major decline in Saudi oil revenues in the 1980s led the government to take a number of policy changes which directly affected the labour market. The government was obliged to reduce the public budget, cut the state's provision of government employment, the state subsidies had to be cut, and there had been a major fall in the Saudi people's per capita income. As a consequence of such economic downfall and to meet the financial demand of the family, many Saudi women were particularly obliged to enter into job market. They started to work more in the public sector to supplement the falling income of the family. Such increasing participation in professions, once largely considered closed to them, have created a space for hiring housemaids to be filled up mostly by the Indonesians, Pilipino and Bangladeshis (Silvey, 2004).

With this increasing demand Saudi government had to invite sending countries to supply female domestic helpers. Thousands of domestic helpers from the South and Southeast Asian countries entered into Saudi Arabia and other Gulf countries. In order to protect the rights of bulk of these housemaids, Saudi government has enacted a number of laws and policies. Both illegal migrants and the employers are brought under punishment procedures. Illegal entry, overstaying without visa and working without valid work permit have been strictly dealt with. Even visa traders who issue fake demands and the employers who employ foreign workers without valid work permit are punished. Despite such strict policies abuse of the domestic workers continue to rise in Saudi Arabia to such an extent that Indonesia and Philippines have recently retreated to send domestic workers from Saudi Arabia (Gartaula, 2011; Silvey, 2004; Almutairi, 2017). 


\section{Macrothink}

Issues in Social Science

ISSN 2329-521X

2018, Vol. 6, No. 1

\section{Plights of Bangladeshi Female Labour Migrants}

Despite attractive financial benefits for the female labour migrants in the Middle Eastern countries, the decision to their migration has recently come under critical scrutiny. This has happed due to unforeseeable plight of Bangladeshi migrant workers that they face abroad. Most of the female domestic helpers are of irregular status which exposes them to a number of abuses, exploitations and sufferings. Many domestic helpers face physical and sexual abuse and are not paid regularly or sufficiently (Frantz, 2017). Many of them are forced to return home with psychological trauma and abuse. There has been a growing discontent among the Bangladeshis that females should not be sent to Middle Eastern countries as domestic helpers. Once these women return home with experiences of sexual abuse and trauma, they face another level of uncertainty and unacceptability in their home society. Many of them are abandoned by their husbands and took shelter in the support centers of BRAC (The daily Star, 2017).

Although government has taken a number of steps to facilitate the smooth process of female migration, the producers are still complicated, unsecured and bureaucratic. Most of the uninformed women in the rural areas are unaware of the procedures of how to registrar and find out information about female labour migration. There has been a gross inadequacy in information dissemination from the government's side. It has also been reported that some government offices such as passport and BMET are corrupt and it requires bribe to get required things done. Government's control and surveillance have been grossly inadequate to curb these mismanagement in the migration process.

Due to complicated government bureaucratic procedures many aspirant female domestic workers are mostly obliged to bypass the formal documentation procedures or unwilling to use of governmental service provisions, which has in fact led to a rapid growth in the business of unregistered migration brokers or dalals. Such informal brokerages have become so widespread in rural Bangladesh that it has already become established like an industry that encourages and even prompts illegal overseas migration. Due to the lack of government monitoring and control, many recruitment agencies have mushroomed in Bangladesh. These recruitment agencies employ dalals in the rural villages to persuade women to seek their services. These labour recruiters and dalals have specific advantages over the aspirant migrants in terms of information about overseas work, knowledge of the destination area, and how to make passports, visa procedures and other relevant activities of labour migration. Such heavy reliance on the dalals and informal agents has adversely affected women and their search for jobs abroad. They become subject to cheating, sexual harassment and psychological abuse (Nahar \& Akond, 2017; The Daily Prothom Alo, 2017; The Daily Star, 2014). In order to work as a domestic helper in the Gulf countries, most female migrants leave their family member and young children in Bangladesh, which further creates social problems as women are still considered as homemakers and childcare providers in Bangladeshi cultural context.

Female domestic workers are abused doubly both at home and in their workplace abroad (Khairuzzaman, 2017; Nahar \& Akond, 2017). They particularly face sexual harassments at 


\section{Macrothink}

Issues in Social Science

ISSN 2329-521X

2018, Vol. 6, No. 1

work. Many newspapers have already reported that hundreds of Bangladeshi female workers are obliged to leave Saudi Arabia due to alleged sexual abuse and torture. Many housemaids flee from their work and take shelter at the Bangladeshi consulate in Riyadh and Jeddah requesting for a protection and repatriation. Many want to return to Bangladesh as they alleged that they did not get the job and salary as promised. The pressure has already been mounted by the social activists, civil society and the media that pressurize the government of Bangladesh to either stop sending female domestic helpers to the Middle Eastern countries until adequate protections are ensured, or effective bi-lateral agreements are signed and enforced to protect the domestic workers abroad.

\section{Conclusion: Opportunities and Challenges of Female Labour Migration}

It has been quite evident in the foregoing discussions that sending female domestic workers to the Gulf countries opens up both an opportunity and challenge for Bangladesh. It has become an opportunity since the receiving countries opens up their labour market for female domestic helpers which creates an opportunity for many underemployed females in Bangladesh to go for a wage earning. For the Government of Bangladesh, sending female domestic helpers creates a bilateral win-win condition between the sending and receiving countries. Moreover, Bangladesh is expected to generate its volume of remittance and national reserve from female labour migration. At the societal level, it is assumed that women's economic opportunity in the form of wage earning would contribute to their empowerment. Women's wage earning could further contribute towards overall wellbeing of the family and the society at large.

Such an opportunity and benefit from female labour migration have soon faded away, since aspirant female migrants face various constraints at home and abroad. Sexual abuse, psychological trauma, irregular payment, insecurity, physical torture appeared as the order of the day. Governments of both sending and receiving countries grossly failed to ensure adequate protection, security and safety measures for female domestic workers. Although several laws, acts and policies are in place, none of them protected female workers as governments of both sending and receiving countries failed to effectively enforce such laws and policies in practice. The dream of many female migrants mostly turns into despair when they are abused in their workplace, obliged to return home and unfortunately unaccepted by their in-laws, as they are culturally considered to be "polluted". Unlike male migration, female migration in Bangladesh has thus become an issue of major contestation.

In order to reap the maximum benefit from female labour migration, all stake holders involved in this process need to play their roles effectively. At the policy level, the following issues could be addressed to make the migration process safe and secured for the women.

- At the level of the sending country like Bangladesh, awareness creation should be the utmost priority. Appropriate and adequate information should be provided so that they know the procedures and become aware of it. Use of social media to disseminate the information could be useful.

- The laws and policies are enough which needs to be effectively implemented. All 


\section{Macrothink

recruiting agencies should bring under strict monitoring and surveillance system.

- Appropriate punishment must be in place to curb the middleman or dalal.

- The overseas embassies should play a proactive role to protect the interest of their female labour migrants.

- There should be rigorous trainings provided for the aspirant migrants about the rules, laws, and culture of the receiving country and their job responsibilities.

- Strong role of the civil society, media and NGOs to keep constant pressure on the government so that appropriate policies are adopted for pro-migration.

The receiving countries should also abide by the ILO convention and ensure that female migrant workers are safe and secured in their country of destination. In case of any abuse or harassment the offenders must be brought under existing laws of the receiving country. Within the prevailing sociocultural and patriarchal norms and practices where women's work is generally devalued and mostly unappreciated, protection and safety of the female labour migrants are unlikely to be attained unless all stakeholders work together to ensure a better working place for them.

\section{References}

Alhasan, H. (2017). Irregular migration in Bahrain: Legislations, policies, and practices. In P. Fargues, \& N. M. Shah (Eds.), Skillful survivals: Irregular migration to the Gulf (pp. 77-94). Jeddah: Gulf Research Center.

Almutairi, A. M. S. (2017). Protecting the rights of temporary foreign 'low-skilled' workers in the Saudi construction industry: A case for legal reform. Unpublished $\mathrm{PhD}$ thesis at the Department of Politics, History and the Brunel Law School, Brunel University London.

Alsharif, F. (2017). Calculated risks, agonies, and hopes: A comparative case study of the undocumented Yemeni and Filipino migrant communities in Jeddah. In P. Fargues, \& N. M. Shah (Eds.), Skillful survivals: Irregular migration to the Gulf (pp. 185-202). Jeddah: Gulf Research Center.

Asia Foundation. (2013). Labour migration trends and patterns: Bangladesh, India, and Nepal. Katmandu: Asia Foundation.

Azhari, A. (2017). The KAFĀLA 'Sponsorship' system in Saudi Arabia: A critical analysis from the perspective of international human rights and Islamic law. The SOAS Journal of Postgraduate Research, 10(17), 61-80.

BMET. (2017). Overseas employment and remittances report 2014. Retrieved from http://www.bmet.org.bd/BMET/stattisticalDataAction\#.

De Bel-Air, F. (2018). Demography, migration and labour market in Saudi Arabia. Jeddah: Gulf Research Center.

Dhaka Tribune. (2017). Overseas migration of female workers on the rise despite reports of 


\section{Macrothink}

Issues in Social Science

ISSN 2329-521X

2018, Vol. 6, No. 1

abuse.

Retrieved

from

https://www.dhakatribune.com/bangladesh/2017/03/28/overseas-migration-female-workers-ri se-despite-reports-abuse

Fargues, P., \& De Bel-air, F. (2015). Migration to the Gulf States: The political economy of exceptionalism. In D. A. Arcarazo, \& A.Wiesbrock (Eds), Global migration: Old assumptions, new dynamics (pp. 139-166). Santa Barbara: ABC-CLIO.

Frantz, E. (2017). The legal production of illegality: Obstacles and opportunities to protect undocumented migrants in the Gulf States. In P. Fargues, \& N. M. Shah (Eds.), Skillful survivals: Irregular migration to the Gulf (pp. 57-76). Jeddah: Gulf Research Center.

Gardner, K. (2009). Lives in motion: The life-course, movement and migration in Bangladesh. $\begin{array}{llll}\text { Journal of south Asian development, } & \text { 4(2), } 251 .\end{array}$ https://doi.org/10.1177/097317410900400204

Gartaula, H. N. (2011). The other side of migration in rural Nepal: Sociocultural transformation and the women left behind. Unpublished $\mathrm{PhD}$ thesis submitted at Wageningen University.

Human Rights Watch. (2014). "I already bought you" Abuse and exploitation of female migrant domestic workers in the United Arab Emirates. New York: Human Rights Watch.

Karim, R. M. (2017). Rents, rent-seeking and corruption in transnational labour migration: A case study of labour migration from Bangladesh to Malaysia. Unpublished thesis submitted to the International Anti-Corruption Academy.

Khairuzzaman, Z. A. M. (2017). Horror and heartbreak in Middle East: Plights of Bangladeshi migrant workers. Labour, 2, 69-81.

Kibria, N. (2011). Working hard for the money: Bangladesh faces challenges of large-scale labour migration. Washington: Migration Policy Institute.

Mahdavi, P. (2017). Producing irregular migration: Living and labouring under laws in the United Arab Emirates. In P. Fargues, \& N. M. Shah (Eds.), Skillful survivals: Irregular migration to the Gulf (pp. 185-202). Jeddah: Gulf Research Center.

Nahar, H. L., \& Akond, A. (2017). Victimization of female migrant workers in countries of destination: A review. Labour, 2, 9-31.

Pakkiasamy, D. (2004). Saudi Arabia's plan for changing its workforce. Washington: Migration Policy Institute.

Papademetriou, D. G. (2005). The global struggle with illegal migration: No end in sight. Washington: Migration Policy Institute.

Saudi Gazette. (2015). Maid recruitment hits roadblocks. Retrieved from http://www.saudigazette.com.sa/article/140685

Shah, N. M. (2008). Recent labour immigration policies in the oil-rich Gulf: How effective 
are they likely to be? Working Paper \#3. International Labour Office; ILO Regional Office for Asia and the Pacific.

Shah, N. M. (2017). Introduction: Skillful survivals - irregular migration to the Gulf. In P. Fargues, \& N. M. Shah (Eds.), Skillful survivals: Irregular migration to the Gulf (pp. 1-12). Jeddah: Gulf Research Center. https://doi.org/10.5406/illinois/9780252039638.003.0001

Silvey, R. (2004). Transnational domestication: State power and Indonesian migrant women in Saudi Arabia. Political Geography, 23, 245-264. https://doi.org/10.1016/j.polgeo.2003.12.015

The Daily Prothom Alo. (2017). Bangladesh women suffer at overseas workplaces. Retrieved from

https://en.prothomalo.com/bangladesh/news/168115/Bangladesh-women-suffer-at-overseasworkplaces

The Daily Star. (2014). Protecting expatriate women workers. Retrieved from http://www.thedailystar.net/editorial/protecting-experiate-women-workers 1509259

The Daily Star. (2017). Agony of female migrant workers. Retrieved from https://www.thedailystar.net/law-our-rights/agony-female-migrant-workers-1540528

\section{Copyright Disclaimer}

Copyright for this article is retained by the author(s), with first publication rights granted to the journal.

This is an open-access article distributed under the terms and conditions of the Creative Commons Attribution license (http://creativecommons.org/licenses/by/3.0/). 